Egyptian Journal of Aquatic Biology \& Fisheries

Zoology Department, Faculty of Science,

Ain Shams University, Cairo, Egypt.

ISSN $1110-6131$

Vol. 24(6): 103 - 116 (2020)

www.ejabf.journals.ekb.eg

\title{
How Culture Medium pH Range Influence Phytoplankton Growth Performance and Biochemical Content
}

\author{
Shymaa S. Zaher*and Amr. M. Helal
}

National Institute of Oceanography and Fisheries,NIOF,Egypt

*Corresponding Author: Shymaasabry2@gmail.com

\section{ARTICLE INFO}

\section{Article History:}

Received: June 29,2020

Accepted: July 29, 2020

Online: Sept.5, 2020

Keywords:

microalgae,

phytoplankton,

Growth Performance,

biochemical constituents, $\mathrm{pH}$ shift,

chlorophyll $a$

\begin{abstract}
The challenge today is to incorporate phytoplankton as a source of protein for food and feed to higher organisms in the food chain. The growth response and total biochemical content of three pure phytoplankton cultures to different ranges of $\mathrm{pH}$ in the synthetic medium were explored under controlled laboratory conditions. The tested species were Chlorella vulgaris Beyerinck [Beijerinck], Nannochloropsis oculata (Droop) D.J.Hibberdand Scenedesmus quadricauda (Turpin) Brébisson. Growth response was determined from acidic to alkaline conditions by chlorophyll values, total biochemical content, proteins, carbohydrates and lipids. The results indicated that the tested species showed different growth patterns and total biochemical content under the same incubation conditions. Generally, the highest biochemical content was total protein followed by carbohydrates and lipids. At $\mathrm{pH}$ (11) of the medium the highest protein peak of Chlorella vulgaris was $\left(68.1 \mathrm{mgl}^{-1}\right)$ and Nannochloropsis oculata was $\left(94.6 \mathrm{mgl}^{-1}\right)$. The maximum protein content of Scenedesmus quadricauda $\left(86.7 \mathrm{mgl}^{-1}\right)$ recorded at $\mathrm{pH}$ (9) of the medium. The best $\mathrm{pH}$ values for growth of tested species were $\mathrm{pH}$ (7) for Chlorella vulgaris and $\mathrm{pH}$ (9) for Nannochloropsis oculata and Scenedesmus quadricauda. A major spot on the highly positive correlation between Nannochloropsis oculata optimum growth and its protein contents $(\mathrm{r}=0.87)$ which indicate that $\mathrm{pH}$ (9) of the medium may be the best one in Nannochloropsis oculata large mass production. The highest carbohydrates and lipids content were detected at acidic conditions of the medium. This study assesses the best $\mathrm{pH}$ conditions needed for optimum growth of particular species to further applying in commercial mass production to get maximum protein yield.
\end{abstract}

\section{INTRODUCTION}

Phytoplankton as autotrophic microorganisms are the basic in food chain for feed to higher planktons as it provide others with energy and the main natural nutrients (Barka and Blecker, 2016). Microalgae usage in aquaculture and its internal biochemical content are primarily depends on its nutritional value, high mass production, ability to withstand fluctuating growth conditions, and being nontoxic, (Muller-Feuga, 2013); 
(Roy and Pal, 2015). Chlorella, Isochrysis, Nannochloropsis, Phaeodactylum, Chaetoceros, Pavlova, and Thalassiosira are commonly used algae in mass production (Muller-Feuga, 2000). Certain species from different phytoplankton classes could overcome stress in natural environment, as they can exceed other microalgae classes, sometimes they vigorously grow and forming bloom generating secondary metabolites in the surrounding aquatic environment (Taheri et al., 2017).

Influence of $\mathrm{pH}$ factor on the metabolic activity, biochemical constituents and ultrastructure of various algae was tested by (Sharma et al., 2012, Safafar et al., 2016). Also light intensity, temperature and minerals affect growth of cyanobacteria detected by (Katoli $\boldsymbol{e t}$ al., 2015). There is a relation between phytoplankton uptake of inorganic carbon during photosynthesis process and increase $\mathrm{pH}$ of the surrounding environment (Hansen, 2002). However, in the algal culture medium $\mathrm{pH}$ is considered one of the most important factors influence optimal algal growth, it controls algal metabolism and affects its bioactive products biosynthesis (Liu and Lee, 2000).

Chlorella spp. and Scenedesmus spp. are green phytoplankton commonly incorporated in food industries because of its high protein and lipid content, (Barka and Blecker, 2016). Nannochloropsis spp. of phytoplankton belongs to Eustigmatophyceae. Although its first record was in marine water (Vareltzis and Undeland, 2012) it commonly recorded in both fresh and marine environment. This species gained its importance from its high biochemical constituents and its possible mass production. A laboratory study about Chlorella spp. use as safe protein source for consumption and dietary supplementation and as natural food for some zooplankton species was tested by (Hegab et al., 2019) and concluded that Chlorella vulgaris is used as food source for Brachionus plicatilis and Heterocypris salina. Zooplankton species grazing and ingestion rates were mainly depending on Chlorella densities. Chlorella vulgaris, Scenedesmus quadricauda and Nannochloropsis oculata are known to be used in biodiesel production (Metsoviti et al., 2019) and as feed for fish (Pulz and Gross, 2004).

Optimization of the conditions of algal cultivation may lead to production of algal biomass in adequate microalgae quantity (Vasileva $\boldsymbol{e t}$ al., 2015).The major scope is using of algae as feed to higher planktons and other organisms in the food web. Microalgae proteins are one of the most important sources of protein to fill the gap in usual protein sources (Barka and Blecker, 2016). Micro algal protein content of Spirulina paltensis constitutes (50-65\%) compared to fish protein (24\%), (Moorhead et al., 2011). Chlorella vulgaris protein constitutes (43-58\% of its dry weight) differs by culture conditions (Safi et al., 2014). Algal usage in different industries in cosmetics, food products enlarge the need for mass production of algae, so there is a growing interest for focus studies on the algal optimum condition needed for optimum growth. So, this study investigate the growth response and total biochemical content of three species of phytoplankton cultured in modified BG11 medium under pH shift from acidic to alkaline conditions. Moreover, large scale production of Chlorella vulgaris is involved.

\section{MATERIALS AND METHODS}

\section{Indoor culture conditions of the tested species}

The phytoplankton species obtained from faculty of girls, Botany Dep., Ain-Shams University. The tested algae were Chlorella vulgaris Beyerinck [Beijerinck], (1890), 
Nannochloropsis oculata (Droop) D.J.Hibberd (1981), and Scenedesmus quadricauda (Turpin) Brébisson, (1835). The selected species belongs to two phytoplankton classes, Chlorophyceae represented by Chlorella and Scendesmus, while Nannochloropsis is from Eustigmatophyte. Through a serious of laboratory work the tested algae become well adapted and grew very well incubated in synthetic modified BG11 medium (Rippka et al., 1979) under sterilized laboratory conditions. The room temperature was $25 \pm 1^{\circ} \mathrm{C}$ and the intensity of light adjusted to $30 \mu \mathrm{Em}^{-2} \mathrm{~s}^{-1}$ under a day / night program of $14 \mathrm{~h}$ light and $10 \mathrm{~h}$ darkness. The algae were harvested in the exponential growth phase. The tested algae were grown under various $\mathrm{pH}$ values of 3,5, 7, 9 and 11. $\mathrm{pH}$ was adjusted using $1 \mathrm{~N} \mathrm{HCL}$ and $1 \mathrm{~N} \mathrm{NaOH}$ solutions using $\mathrm{pH}$ meter model (WTWph91) . Three replicates were made for each $\mathrm{pH}$ value for tested species. These experiments were done in $500 \mathrm{ml}$ conical polycarbonate Erlenmeyer flasks kept under controlled laboratory condition. For each species definite samples were filtered on glass GF/F filter paper (whatman $0.7 \mu \mathrm{m}$ ). Chlorophyll $a$ detection was used for determining algal growth. The concentrations of chlorophyll $a$ were calculated according to the trichromatic equation (Apha, 1995).

Total Biochemical contents were detected for each micro algal species, Biuret method was used for total protein detection, using Biuret reagent. Bovine Serum Albumin (BSA) used as standard for protein. For each sample and standard Biuret reagent was added then incubated for 30 minutes at room temperature then measured by absorption spectroscopy at $540 \mathrm{~nm}$, (David James and Hazel, 1994) . Carbohydrate contents were measured at $480 \mathrm{~nm}$ according to Phenol sulphuric acid hydrolysis method as described by (Dubois $\boldsymbol{e} t$ al., 1956), employing glucose as standard. The total lipid content was estimated by the Sulphophosphovanillin procedure utilizing cholesterol as calibration standard, the absorbance of the characteristic pale pink color was measured at 525nm (Chabrol and Castellano, 1961).

Chlorophyll $a$ and the total biochemical constituents were estimated using Kontron 930 UV visible Spectrophotometer. From the three tested species Chlorella vulgaris was selected for both indoor and large scale cultivation. Indoor experiments have been used modified BG11 medium under sterilized laboratory conditions.

\section{Outdoor Culture conditions of Chlorella vulgaris for large scale production}

The large scale cultivation of the tested species was carried out at Heliopolis University, Faculty of Engineering, the green house ( STDF project), the water source is underground water well that separated through Reverse Osmosis( RO) device into saline and fresh water. The separated fresh water is used in Chlorella vulgaris large scale production. From $500 \mathrm{ml}$ conical polycarbonate Erlenmeyer flasks to transparent plastic tank $(70 \mathrm{~L})$ as intermediary stage (plate 1$), 3 \mathrm{~m}^{3}$ tanks in raceway, filled with fresh ground water and pure nutrient medium inoculated with culture of Chlorella vulgaris with 5\% of the tank water volume. Continuous aeration with paddle wheel is supplied for algal oxygen demands and to keep the culture medium in suspension (plate 2). Keep the tanks in open air outdoor conditions and average temperature was $25-30{ }^{\circ} \mathrm{C}$ for 14 days to harvest the required algal concentrations. Time of harvest begin by detecting transparency with secchi desk when transparency value reached $2 \mathrm{~cm}$ the harvest begin. Special net mesh size of $5 \mu$ is used for harvest algae (plate 3). The harvested algae dried 
at oven at $60^{\circ} \mathrm{C}$ to gain pure powder of Chlorella. For outdoor algal production the Amaral's medium was used (Pecegueiro do Amaral, 2012).
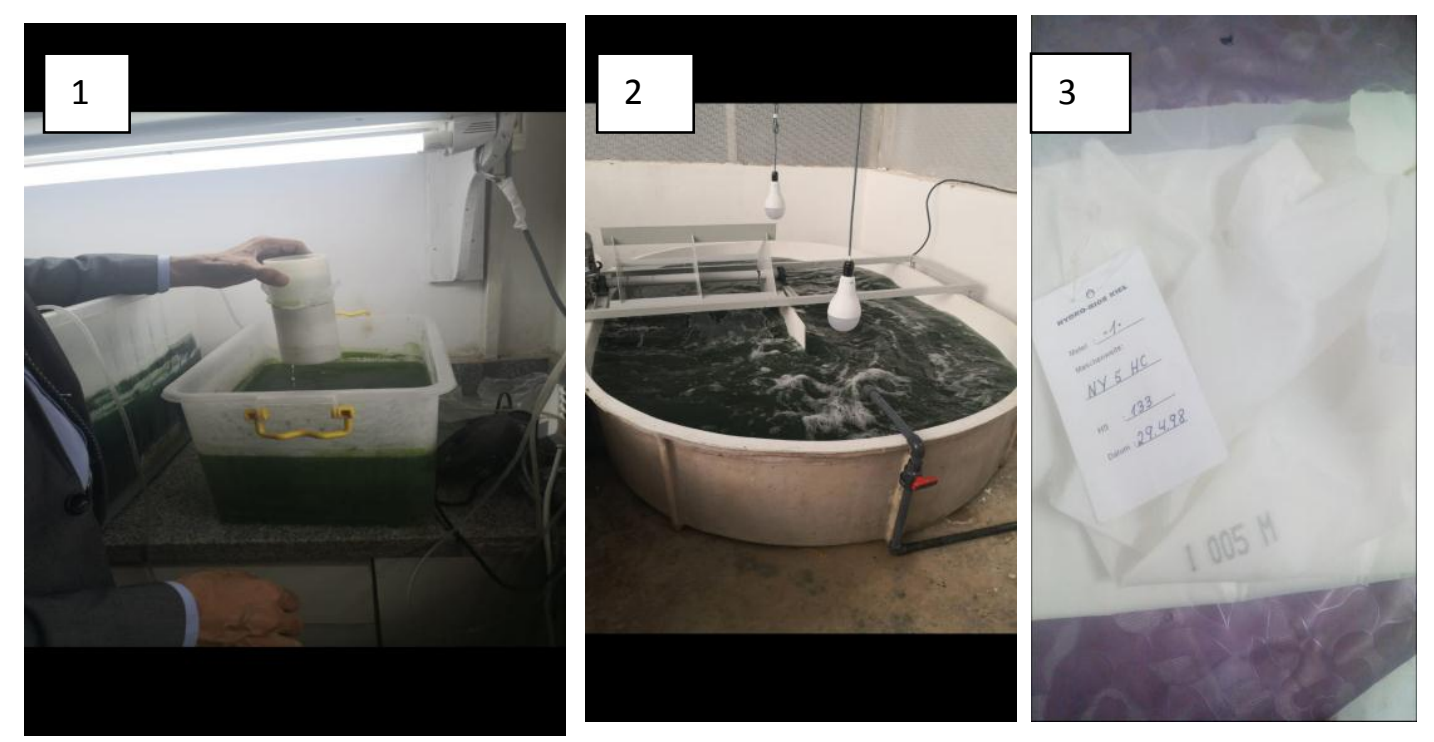

\section{Plates:}

(1): Transparent plastic tank of Chlorella vulgaris used as intermediate stage in the laboratory before mass production.

(2): Tank of Chlorella vulgaris for large mass production showing the peddle wheel for continuous aeration

(3): Net mesh size of $5 \mu$ for algal harvest.

\section{STATISTICAL ANALYSIS}

Determination of algal growth as represented by chlorophyll $a$ concentrations and total biochemical content were statistically analyzed using (StatSoft, 2011) . Correlation and one way analysis of variance (ANOVA) were used to examine the independent effects as well as possible interactions.

\section{RESULTS}

\section{1- Effect of different $\mathrm{pH}$ level on the tested phytoplankton species growth as representing by chlorophyll $a$ concentrations}

Growth response represented by chlorophyll $a$ values of tested phytoplankton species were assessed during the present study under controlled laboratory conditions. The results showed that phytoplankton species recorded different growth pattern in spite of the similarity in the incubation conditions. Chlorophyll $a$ concentrations of the phytoplankton species are illustrated in Figure (1). 


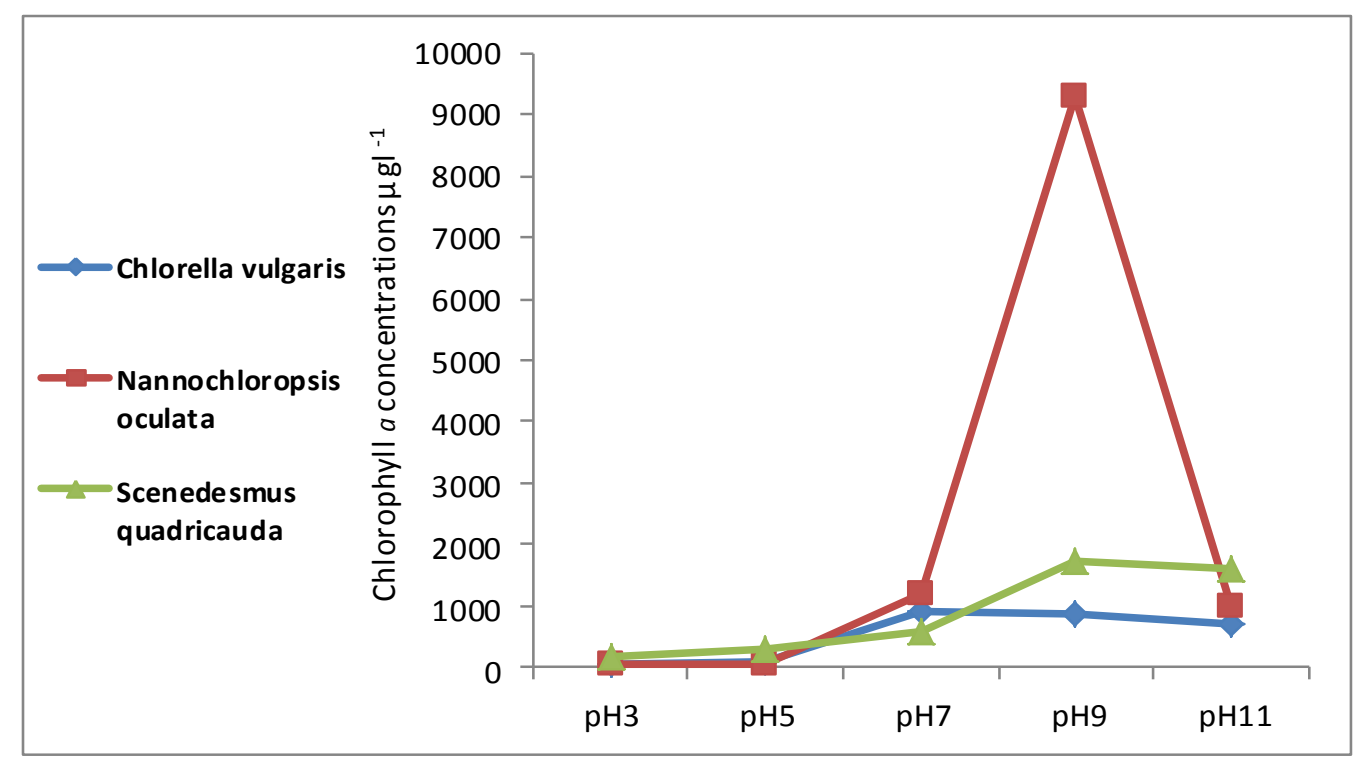

Figure (1): Chlorophyll $a$ values $\left(\mu \mathrm{gl}^{-1}\right)$ of three phytoplankton species at different $\mathrm{pH}$ values.

\section{1a - Chlorella vulgaris}

Chlorophyll $a$ concentrations for $C$. vulgaris attained its lowest concentrations at $\mathrm{pH} 3$ $\left(47.3 \mathrm{\mu gl}^{-1}\right)$ and the maximum one at $\mathrm{pH} 7\left(918 \mu \mathrm{gl}{ }^{-1}\right)$. Gradual decrease in values was detected at $\mathrm{pH}(9)$ and till it reached $\left(695.2 \mu \mathrm{gl}^{-1}\right)$ at $\mathrm{pH}(11)$ of the medium. Chlorophyll $a$ of $C$. vulgaris showed a positive correlation with total protein contents $(\mathrm{r}=0.629)$ however strong negative correlation detected with carbohydrates $(r=-0.99)$ and lipids $(r=$ $-0.6)$.

\section{1b-Nannochloropsis oculata}

Growth of $N$. oculata showed considerably lower values of chlorophyll $a$ at $\mathrm{pH}$ (3) and $\mathrm{pH} 5\left(47.1 \mu \mathrm{gl}^{-1}\right.$ and $51.2 \mu \mathrm{gl}{ }^{-1}$ respectively), while its highest peak was recorded at $\mathrm{pH}$ (9) when reached $\left(9284.1 \mu \mathrm{gl}^{-1}\right)$, then its value decreased to $\left(1005.07 \mu \mathrm{gl}{ }^{-1}\right)$ at $\mathrm{pH}(11)$ of the medium. Special interest to the major peak of $N$. oculata recorded at $\mathrm{pH}(9)$ compared with the other tested species as shown in Figure (1). N. oculata growth as represented by chlorophyll $a$ recorded high positive correlation with proteins and total biochemical contents ( $r=0.87 \& 0.83$ respectively).

\section{1c-Scenedesmus quadricauda}

Chlorophyll a concentrations of $S$. quadricauda showed different pattern of growth as it recorded higher values compared with other species. At $\mathrm{pH}$ (3) of the medium chlorophyll $a$ value was $\left(174.9 \mu \mathrm{gl}^{-1}\right)$, while it recorded $\left(604.6 \mu \mathrm{gl}^{-1}\right)$ at $\mathrm{pH}(7)$, and then it reached the highest value of $\left(1750.9 \mathrm{gl}^{-1}\right)$ at $\mathrm{pH}(9)$ of the medium. Growth of $S$. quadricauda was weakly correlated with protein and total biochemical contents but correlate negatively with carbohydrates and lipids $(-0.61 \&-0.54)$. 
ANOVA analysis indicated significant differences attributed to the effect of $\mathrm{pH}$ shift on chlorophyll $a$ between different species.

\section{2- Effect of different $\mathrm{pH}$ level on phytoplankton total biochemical contents}

The total biochemical contents of the selected species were detected at different $\mathrm{pH}$ range of the medium under laboratory conditions as shown in Figures (2, 3 and 4). Generally the highest biochemical content was total proteins followed by carbohydrates and lipids. "There were statistically significant differences between group means as determined by one-way ANOVA in both of $C$. vulgaris $(\mathrm{F}(4,20)=6.71, \mathrm{p}=0.0013)$ and $S$. quadricauda $(\mathrm{F}(4,20)=6.66 . \mathrm{p}=0.0014)$. However ANOVA results showed nonsignificant difference in $N$. oculata species $(F(4,20)=1.68, p=0.19)$. For all tested species when medium tend to acidic conditions especially at $\mathrm{pH}$ (3) the highest carbohydrates content were recorded.

\section{2a-Chlorella vulgaris}

Total biochemical contents of $C$. vulgaris (Figure 2) showed more or less similar concentrations at $\mathrm{pH}(3,5$ and 7$)$ with average of $\left(56.8 \mathrm{mgl}^{-1}\right)$, then it slightly increased to $\left(67.9 \mathrm{mgl}^{-1}\right)$ at $\mathrm{pH}(9)$ reached its highest concentration of $\left(74.2 \mathrm{mgl}^{-1}\right)$ at $\mathrm{pH}(11)$ of the medium. The detected protein contents of $C$. vulgaris showed slightly gradual increase to a certain extent as $\mathrm{pH}$ increase from $\mathrm{pH} 3\left(45.6 \mathrm{mgl}^{-1}\right)$ till reaching the highest values at $\mathrm{pH} 11\left(68.2 \mathrm{mgl}^{-1}\right)$ of the medium. Carbohydrates contents of $C$ .vulgaris were in the same range at $\mathrm{pH}(7,9$ and 11) while it reached its highest concentrations when the medium tends to the acidic condition $\left(9.5\right.$ and10 mgl $\left.{ }^{-1}\right)$ at $\mathrm{pH}$ (5and 3) respectively. Lipid contents of $C$.vulgaris were the lowest one ranged from (1.25 to $2 \mathrm{mgl}^{-1}$ ) at $\mathrm{pH}(11)$ and $\mathrm{pH}(3)$ respectively. Positive correlation was recorded between carbohydrates and lipids $(r=0.67)$. Total biochemical contents showed strong positive correlation with Chlorella proteins $(\mathrm{r}=0.96)$ and strong negative correlation with its lipids contents $(\mathrm{r}=-0.905)$.

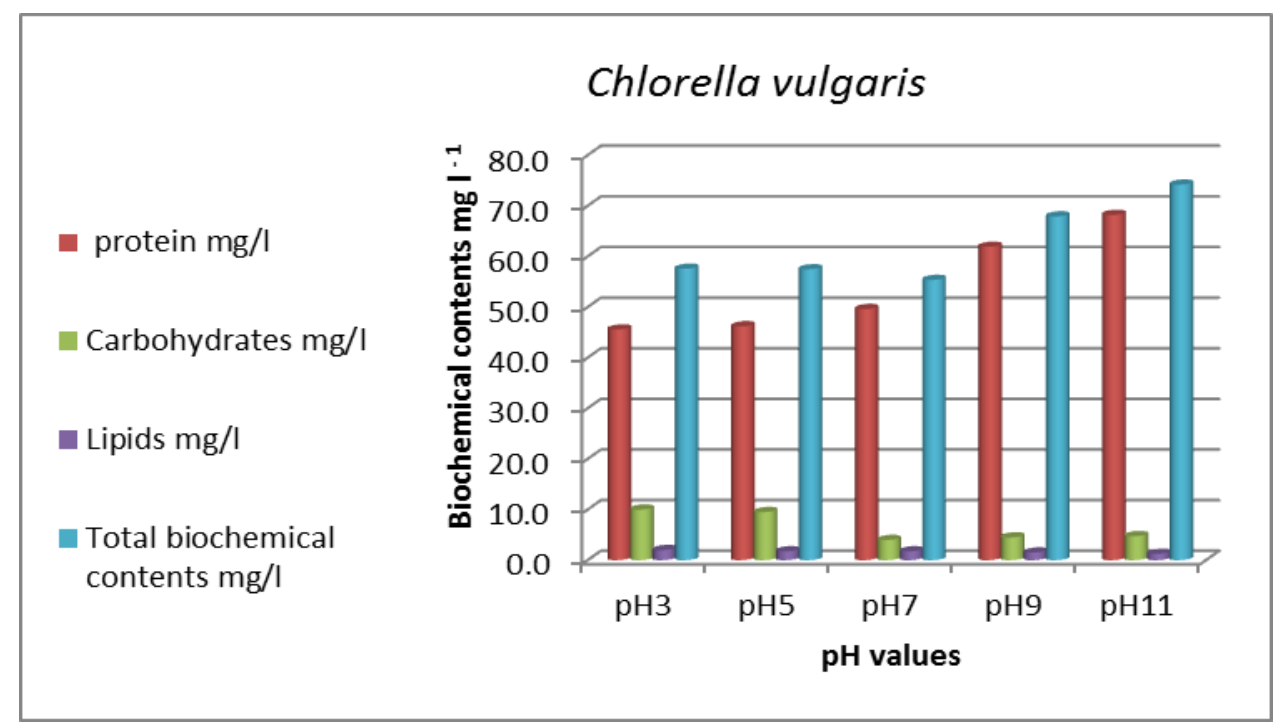

Figure (2): Total biochemical contents $\left(\mathrm{mgl}^{-1}\right)$ of Chlorella vulgaris under various $\mathrm{pH}$ levels. 


\section{2b- Nannochloropsis oculata}

Total biochemical contents of $N$. oculata (Figure 3) attained its highest concentrations $\left(102.36 \mathrm{mgl}^{-1}\right)$ at $\mathrm{pH}(9)$, this value related to high protein contents which confirmed by highly positive correlation $(\mathrm{r}=0.99)$, while the lowest total biochemical contents of $\left(42.15 \mathrm{mgl}^{-1}\right)$ recorded at $\mathrm{pH}(5)$ with lowest protein values. The tested species N.oculata was greatly affected by the $\mathrm{pH}$ shift in the growth medium attained protein contents of (59.8 and $57.4 \mathrm{mgl}^{-1}$ ) at $\mathrm{pH}$ (3) and (11) respectively. This species recorded sharp significant reduction of protein yield $\left(32.7 \mathrm{mgl}^{-1}\right)$ at $\mathrm{pH}(5)$ and the highest protein peak of $\left(94.6 \mathrm{mgl}^{-1}\right)$ was recorded at $\mathrm{pH}$ (9). A major interest in carbohydrates content of $N$. oculata attained the same carbohydrates level $\left(11.1 \mathrm{mgl}^{-1}\right)$ at the two extremes of acidic and basic conditions. The lowest value of $\left(5.75 \mathrm{mgl}^{-1}\right)$ was recorded at $\mathrm{pH}(9)$ of the medium. Lipid values were approximately in the same range at different $\mathrm{pH}$ values in average of $\left(1.8 \mathrm{mgl}^{-1}\right)$. There is no significance difference between biochemical contents of $N$. oculata due the course of this study.

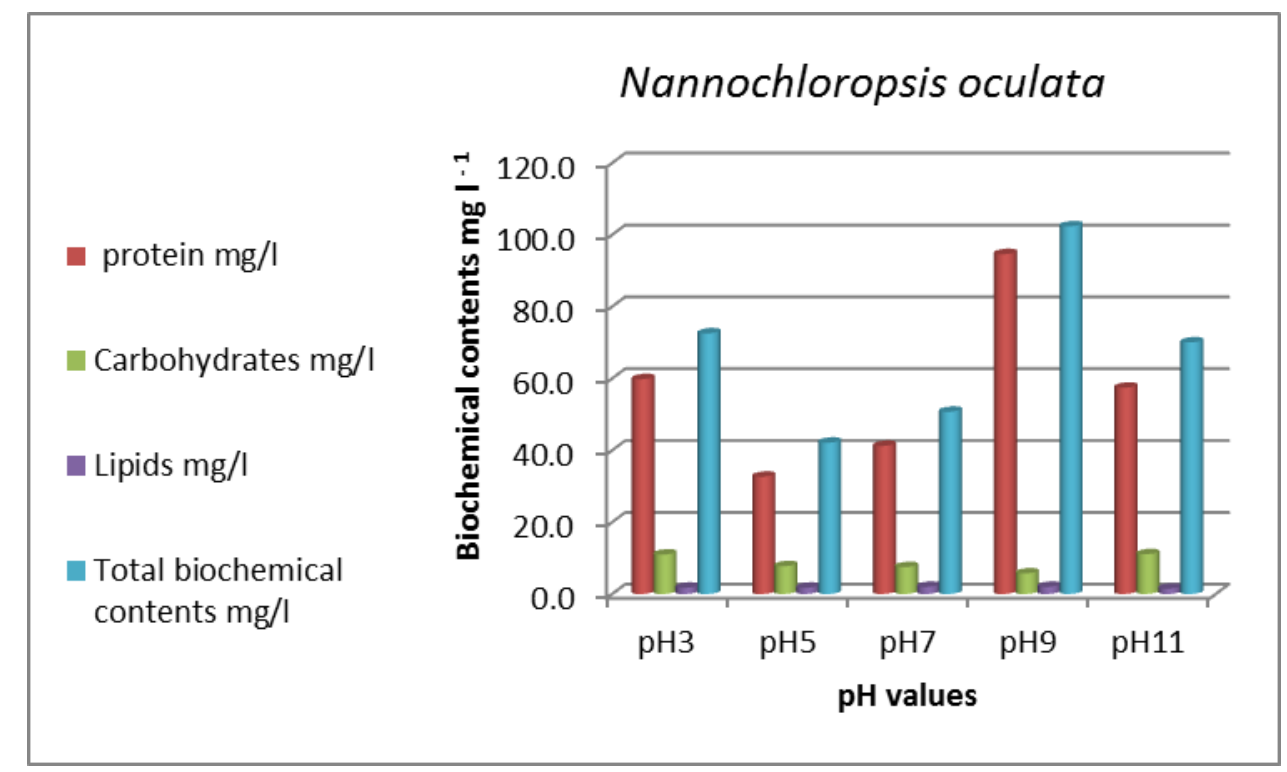

Figure (3): Total biochemical contents $\left(\mathrm{mgl}^{-1}\right)$ of Nannochloropsis oculata under various $\mathrm{pH}$ levels

\section{2c-Scenedesmus quadricauda}

The total biochemical contents of S. quadricauda (Figure 4) recorded the highest average value of $\left(78.61 \mathrm{mgl}^{-1}\right)$ compared with other species. The maximum value was recorded when the medium tends to alkaline conditions at $\mathrm{pH}(9)$ while the minimum of (67.69 $\mathrm{mgl}^{-1}$ ) was recorded towards the acidic conditions at $\mathrm{pH}$ (3) of the medium. $S$. quadricauda maximum protein content of $\left(86.8 \mathrm{mgl}^{-1}\right)$ was recorded at $\mathrm{pH}(9)$ and the minimum of $\left(57.2 \mathrm{mgl}^{-1}\right)$ was recorded at $\mathrm{pH}(3)$. The maximum carbohydrate content of $\left(8.5 \mathrm{mgl}^{-1}\right)$ was at $\mathrm{pH}(3)$ and the minimum of $\left(6 \mathrm{mgl}^{-1}\right)$ was at $\mathrm{pH}$ (9). Lipid contents of S. quadricauda take the same trend as those of carbohydrates achieving its highest level of $\left(2.0 \mathrm{mgl}^{-1}\right)$ at $\mathrm{pH}(3)$ and the lower of $\left(1.0 \mathrm{mgl}^{-1}\right)$ at $\mathrm{pH}(7)$.

S. quadricauda showed highly positive correlation between its total biochemical contents and protein $(r=0.99)$ also between carbohydrates and lipids contents $(r=0.89)$. However 
negative correlations were detected for carbohydrates and protein \& its total biochemical contents ( $\mathrm{r}=-0.74 \&-0.67$ respectively).

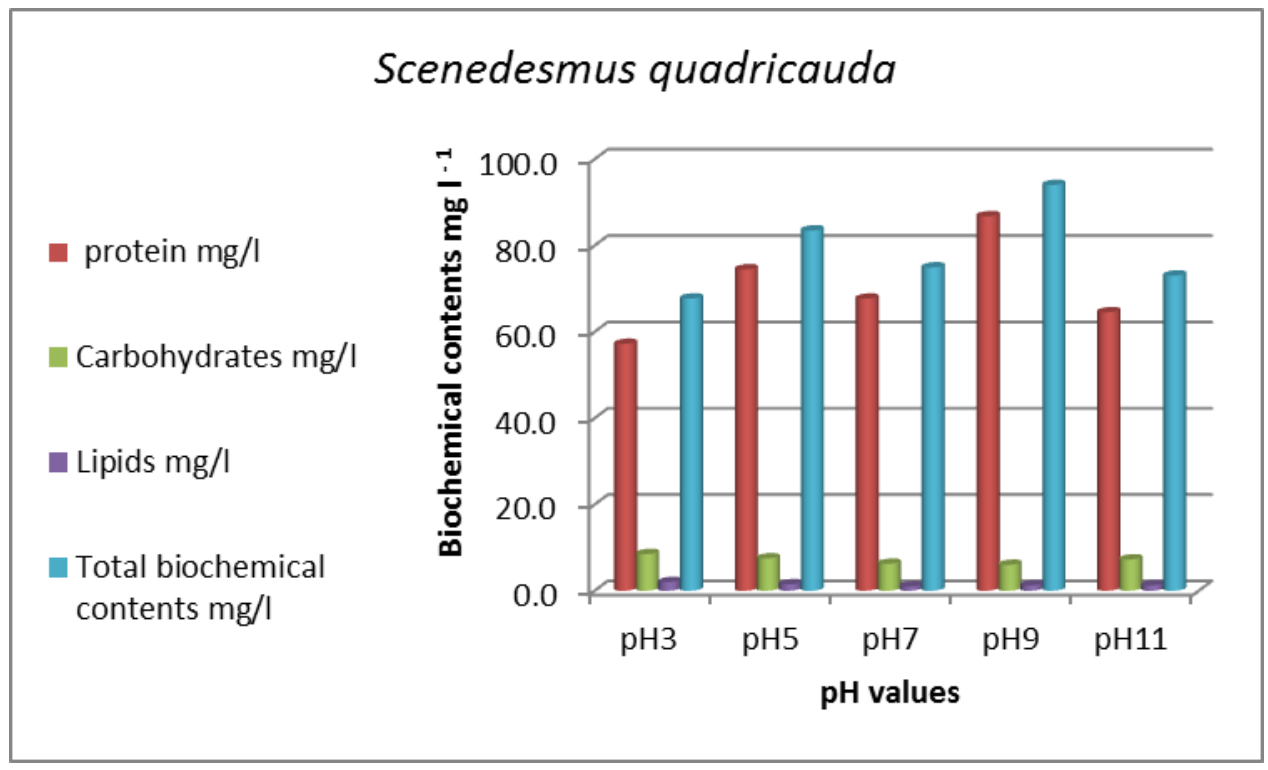

Figure (4): Total biochemical contents $\left(\mathrm{mgl}^{-1}\right)$ of Scenedesmus quadricauda under various $\mathrm{pH}$ levels.

Total biochemical contents percentage $(\%)$ of the tested species differed from species to another showed special variation at different $\mathrm{pH}$ levels. Figure (5) represents the percentage (\%) of total proteins, total carbohydrates and total lipids at $\mathrm{pH}(7)$ of the medium as control.

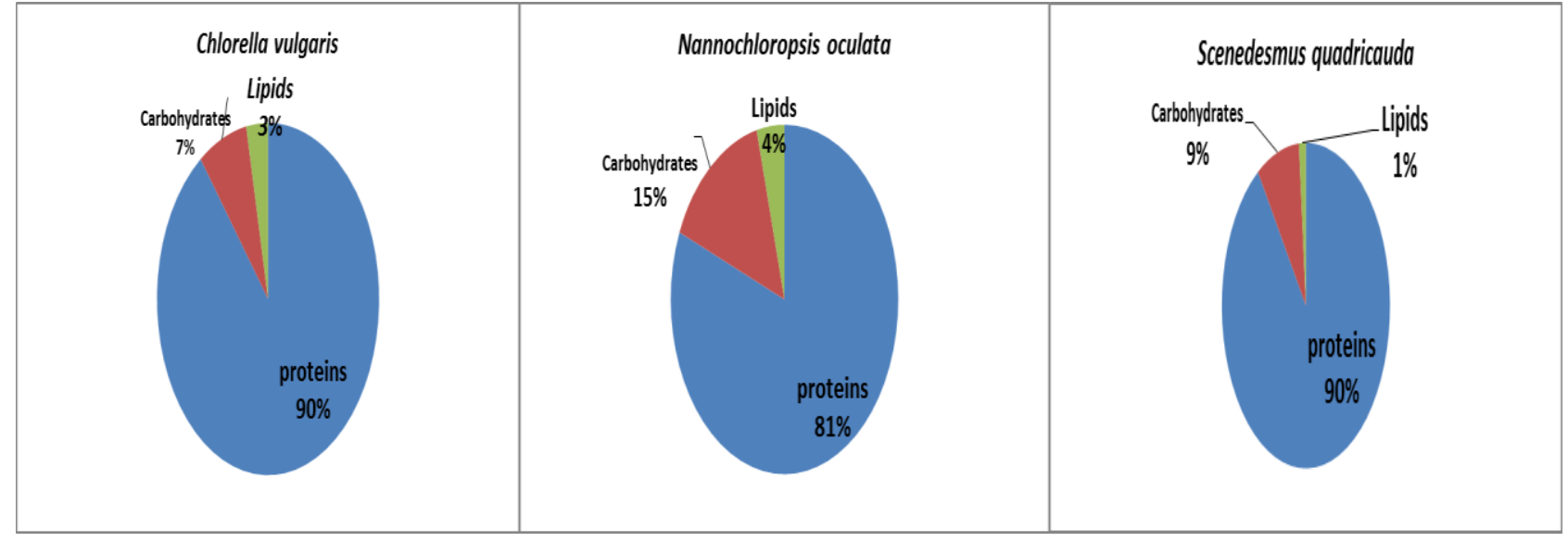

Figure (5): Biochemical contents percentage (Proteins, Carbohydrates and Lipids ) of the three tested species at control conditions, $\mathrm{pH}$ (7) of BG11 medium under laboratory conditions.

For C. vulgaris proteins were $90 \%$ while carbohydrates represent $7 \%$ and only $3 \%$ for lipids. N. oculata protein percent attained $81 \%$ while carbohydrates were $15 \%$ with $4 \%$ lipids contents. For S. quadricauda protein percentage was $90 \%$ while carbohydrates represent $9 \%$ with minor lipids of $1 \%$. 


\section{3- Outdoor Cultivation of Chlorella vulgaris for large scale production}

The present results confirmed that $C$. vulgaris contain high total biochemical contents and high protein contents moreover under stress conditions especially when $\mathrm{pH}$ shifts to acidic conditions $C$. vulgaris can accumulate more carbohydrates and lipids content. For these reasons, this species was selected for cultivation for large mass production. In large scale mass production, commercial medium was used instead of the synthetic medium. This includes modification in the medium components by adding commercial fertilizers as urea and phosphoric acid as considerably low cost components. The implementation of this technique has achieved promising results in commercial farms (personal communication).

\section{DISCUSSION}

Microalgae response to stress in the surrounding medium are greatly fluctuated and $\mathrm{pH}$ shift consequently affect phytoplankton growth performance and its biochemical profile. $\mathrm{pH}$ of the medium is largely affected on $\mathrm{CO}_{2}$ solubility, availability and its role on the essential nutrients in algal metabolism are considered (Chen and Durbin, 1994). The suitable $\mathrm{pH}$ of the growth differs from species to another. Chlorophyll $a$ concentrations of the tested species grown in BG11 attained the maximum values (at $\mathrm{pH}$ from 7 to 9) from neutral to slightly alkaline conditions, then its values tended to decrease by shifting the medium to acidic or basic conditions. (Falkowski and Raven, 1997) observed inhibition in growth of Chlorella as represented by chlorophyll $a$ concentrations at $\mathrm{pH}$ (11) of the medium, at high alkaline $\mathrm{pH}$, almost no carbon is accessible for the algae because carbonate ion $\left(\mathrm{CO}_{3}{ }^{2-}\right)$ is the dominant form of inorganic carbon and the bicarbonate ion $\left(\mathrm{HCO}_{3}{ }^{-}\right)$is the form utilized by the microorganisms (Azov, 1982). Limitation in $\mathrm{CO}_{2}$ supply which potentially reduces the phytoplankton growth, influence the inter-speciation of inorganic carbon (as $\mathrm{CO}_{2}, \mathrm{HCO}_{3}{ }^{-}, \mathrm{CO}_{3}{ }^{2-}$ ) may be from reasons of inhibition of phytoplankton growth at high $\mathrm{pH}$ values (Barka and Blecker, 2016). Nannochloropsis species attained its optimum growth values as detected by chlorophyll $a$ at $\mathrm{pH}$ (9). (Hu and Gao, 2006) recorded the optimum $\mathrm{pH}$ for Nannochloropsis salina ranged from (7.5 to 8.5), while in other experiment doing on Nannochloropsis salina by (Safafar et al., 2016) the growth at $\mathrm{pH}(6.3)$, was significantly lower than at higher $\mathrm{pH}$ values. The same results recorded by (Schmidt and Hansen, 2001) when the marine phytoplankton cultures grown in $\mathrm{f} / 2$ medium showed obvious inhibition in growth at higher $\mathrm{pH}$ more than those caused by high nutrients (N and P). Scenedesmus quadricauda achieved its highest value of growth as represented by chlorophyll $a$ concentrations at $\mathrm{pH}$ (9) of the medium, the same results obtained by (Bakuei et al., 2015) who recorded high growth of Scendesmus in alkaline conditions at $\mathrm{pH} 8$ of the medium. As photosynthesis process of algae is deeply affected by $\mathrm{pH}$ of the medium, alkaline condition preferred for algal cultivation (Bakuei et al., 2015).

In the present study, high protein contents was detected at $\mathrm{pH}$ (11) for Chlorella (91.9\%) however high values were detected at $\mathrm{pH}$ (9) for Nannochloropsis (92.4\%) and Scenedesmus $(92.2 \%)$, it seems that these $\mathrm{pH}$ values stimulate protein production in comparison with its lower value at $\mathrm{pH}$ (3). Strong positive correlation of Nannochloropsis oculata growth with total proteins contents $(\mathrm{r}=0.87)$ indicated that $\mathrm{pH}$ 
(9) of the growth medium of this species is the best one to produce higher protein content, so the result of this study recommended $\mathrm{pH}(9)$ as the best value for growth of $N$. oculata in large scale production to obtain optimum protein contents. However, further studies must be performed on commercial medium used in algal mass production.

Safafar et al. (2016) recorded higher biochemical contents in C.vulgaris and C.minor were at $\mathrm{pH}$ (9). Protein contents in plankton have been relatively less studied compared with its lipids. Proteins are the basic organic components in cells except during storage of carbohydrates and lipids. Microalgae contain high proteins contents, Chlorella vulgaris contain 51-58\%, (Enyidi, 2017) Scenedesmus obliquus contain 48-55\% (López et al., 2010). Protein content in Nannochloropsis salina are 39\% (Safafar et al., 2016). Protein from microalgae as natural source can be used as an animal protein replacement e.g Chlorella protein, which in turn may have positive effect on the environment (Jones, 2016).

All the tested species recorded its highest carbohydrates contents at $\mathrm{pH}$ (3) of the medium, for Chlorella (17.3\%), Nannochloropsis (15.1\%) and Scenedesmus (12.5\%). The highest lipid contents of Chlorella (3.4\%) and Scenedesmus (2.9\%) were at $\mathrm{pH}(3)$ of the medium while, Nannochloropsis high lipid contents $(4.1 \%)$ was recorded at $\mathrm{pH}(5)$ of the medium. The high carbohydrate and lipid contents of the tested species recorded in acidic condition of $\mathrm{pH}$ may be a mode of adaptation of these algae, science some algae adapt to the medium acidic condition by accumulating of more lipids. Dunaleilla acidophila accumulating glycerol to adapt to acidic conditions and avoid osmotic imbalance (Fuggi et al., 1988) storage of lipids also detected in Chlamydomonas and pinnilaria braunii var. amplicephala under highly acidic conditions (Tatsuzawa et al., 1996). Maintenance of neutral intracellular $\mathrm{pH}$ in acidic conditions of medium require excessive energy to pump protons out of the cell (Terry and Abadía, 1986) so, algae need to store carbohydrates, this explain the high lipid and carbohydrates content of the tested species under acidic condition of the medium.

Phytoplankton compositions in case of cultured medium differ from those grown in natural habitat, during the exponential growth phase protein is the dominant while carbohydrates, mainly soluble sugars, stored during stationary phase, (Platt and Irwin, 1973), total protein content values differ from $13 \%$ and $59 \%$ of the phytoplankton dry weight for cultured (Strickland, 1968) and natural habitat (Platt and Irwin, 1973). The previous authors indicated that the variations are basically related to the physicochemical factors of the environment and to a lesser extent on the algal growth stage. (Xia et al., 2014) assessed the high protein content of Scenedesmus sp. also its high lipid content and biomass productivity. Microalgae species e.g Scenedesmus sp. and Chlorella sp. are almost being produced for biofuel synthesis, and after lipid extraction the by-product obtained can be readily valorized for its high protein content. (López et al., 2010) determined that for most microalgae the protein contents vary widely from 30 to 55\% depending on the cell disruption pre-treatment method applied the strain and the growth medium nature.

Identifying the optimum growth conditions for algal growth lead to production of enough mass production of microalgae, (Vasileva et al., 2015) then usage the dried form of these algae in synthetic feed lead to determination of the so called, techno functional properties of protein, this term describe the protein properties that is plus their nutritional function 
are able to have important role in food formulation. These properties are deeply involved in enhancing the organoleptic characteristics of processed food, including texture, viscosity, palatability and mouth feel. This described by (Amita and Ahluwalia, 2010) who compared native and chemically modified Spirulina proteins for their functional properties. The author found that Spirulina protein solubility in water decreased considerably when treated with succinic anhydride, acetic anhydride and formaldehyde. Foam stability was found to be higher with methylation and acetylation. Maximum viscosity was obtained with the succinic anhydride modified protein fraction followed by acetylation.

As phytoplankton considered a very good source of protein that have beneficial nutritional properties and in turn its use in fish feed need mass production so, studying all the optimum condition needed for optimum growth and maximum protein yield are recommended. Also, microalga mass production needs to be encouraged by public authorities to overcome food shortages for the increased world population. Studying the algal product status from the point of view its toxicology, microbiology and its biochemical contents must be assessed before its complete integration as basic components into processed foods and feed.

Selection of $C$. vulgaris for cultivation and mass production mainly due to it is one of the most studied and commercially produced algae known to have several biochemical components with extensive range of applications in different fields (Ru et al., 2020).

C. vulgaris employed for human consumption has high proteins, vitamins, minerals, and polyunsaturated fatty acids (Becker, (2007);Liu and Hu, (2013);Chacón-Lee and González-Mariño, (2010) ;Petkov and Garcia, (2007). C. vulgaris protein constitutes (43-58\%) while, lipid content forms 5-58\%, (Safi et al., 2014), moreover carbohydrate content can reach up to (12-55\%) dry weight especially when cultured under unfavorable conditions like, limited nitrogen conditions (Choix et al., 2012).

Algal usage for food and feed need large mass production but face high cost so, selection of commercial medium drop the costs for algal large scale production. Considerable rise in algal mass production costs is the primary reason for restricting further applications of these microalgae (Wijffels and Barbosa, 2010).

Economical microalgal mass production need significant reduction in cost in order to be more competitive and sustainable (Zittelli et al., 2013). Commercial medium production depends on replacement of high cost medium components by another considerably low cost components as verified by (Abou El-Kheir et al., 2016) who succeeded in modification of Zarouk medium for large scale Spirulina production by using urea and phosphoric acid as commercial fertilizers. The same technique was used in Chlorella large scale production (Hasanein et al., 2018). In this field, ongoing studies and techniques are recommended for developing commercial low costs medium for outdoor large scale algal production.

\section{CONCLUSION}

Based on the results it is clear that, the habituation behavior of the three tested alga seems to be different at various $\mathrm{pH}$ range. The best $\mathrm{pH}$ values for chlorophyll $a$ production were $\mathrm{pH}$ (7) for Chlorella vulgaris and $\mathrm{pH}$ (9) for Nannochloropsis oculata and Scenedesmus quadricauda. There is a limitation in growth of the tested phytoplankton species at 
elevated levels of $\mathrm{pH}$ medium. High protein contents for $C$. vulgaris obtained at $\mathrm{pH}$ (11) while, for $N$. oculata and $S$. quadricauda were at $\mathrm{pH}$ (9). Generally, the highest carbohydrates and lipids contents were at acidic conditions of the medium. These experiments depend on particular species grown as well as on definite growth medium, which could bring useful data for full scale mass production. The tested algal species need more intensive researches on economic commercial culture conditions to cope with challenge in algal mass production.

\section{ACKNOWELDGEMENT}

The authors express appreciation to Dr. Howayda Abd-El-Hady for helping in carbohydrates and lipid data calculations.

\section{REFERENCES}

Abou El-Kheir, W. ; Ibrahim, E. ; Abd El-Razek, A. and Helal, A. (2016). Effect of drying processes on biochemical contents of Spirulina platensis as a protein source for fish diet. Journal of Environmental Science 32(1): 1-23.

Amita, M. and Ahluwalia, A. (2010). Effect of processing on functional properties of Spirulina protein preparations. African Journal of Microbiology Research 4(1): 5560.

Apha, A. (1995). WEF, 1998. Standard methods for the examination of water and wastewater 20.

Azov, Y. (1982). Effect of pH on inorganic carbon uptake in algal cultures. Appl. Environ. Microbiol. 43(6): 1300-1306.

Bakuei, N. ; Amini, G. ; Najafpour, G. D. ; Jahanshahi, M. and Mohammadi, M. (2015). Optimal cultivation of Scenedesmus sp. microalgae in a bubble column photobioreactor.

Barka, A. and Blecker, C. (2016). Microalgae as a potential source of single-cell proteins. A review. Base 20(3): 427-436.

Becker, E. W. (2007). Micro-algae as a source of protein. Biotechnology advances 25(2): 207-210.

Chabrol, E. and Castellano, A. (1961). SPV method for estimation of total serum lipid. J. Lab. Clin. Med 57: 300.

Chacón-Lee, T. and González-Mariño, G. E. (2010). Microalgae for "healthy" foodspossibilities and challenges. Comprehensive reviews in food science and food safety 9(6): 655-675.

Chen, C. Y. and Durbin, E. G. (1994). Effects of pH on the growth and carbon uptake of marine phytoplankton. Marine Ecology-Progress Series 109: 83-83.

Choix, F. J. ; De-Bashan, L. E. and Bashan, Y. (2012). Enhanced accumulation of starch and total carbohydrates in alginate-immobilized Chlorella spp. induced by Azospirillum brasilense: II. Heterotrophic conditions. Enzyme and microbial technology 51(5): 300-309.

David James, H. and Hazel, P. (1994). Problem solving in analytical biochemistry, Longman.

Dubois, M. ; Gilles, K. A. ; Hamilton, J. K. ; Rebers, P. t. and Smith, F. (1956). Colorimetric method for determination of sugars and related substances. Analytical chemistry 28(3): 350-356. 
Enyidi, U. (2017). Chlorella vulgaris as Protein Source in the Diets of African Catfish Clarias gariepinus. Fishes 2(4): 17.

Falkowski, P. and Raven, J. (1997). Aquatic photosynthesis, 375. Malden: Blackwell Science.

Fuggi, A. ; Pinto, G. ; Pollio, A. and Taddei, R. (1988). The role of glycerol in osmoregulation of the acidophilic alga Dunaliella acidophila (Volvocales, Chlorophyta): effect of solute stress on photosynthesis, respiration and glycerol synthesis. Phycologia 27(4): 439-446.

Hansen, P. J. (2002). Effect of high $\mathrm{pH}$ on the growth and survival of marine phytoplankton: implications for species succession. Aquatic microbial ecology 28(3): 279-288.

Hasanein, S. ; Saleh, N. E. ; El-Sayed, H. and Helal, A. (2018). The Effect of dietary supplementation of Spirulina platensis and Chlorella vulgaris algae on the growth and disease resistance of the sea bass (Dicentrarchus labrax). Egyptian Journal of Aquatic Biology and Fisheries 22(4): 249-262.

Hegab, M. ; Zaher, S. and A. Mola, H. (2019). The consumption rate of three zooplankton species of different size fed on the green microalgae Chlorella vulgaris. Egyptian Journal of Aquatic Biology and Fisheries 23(2): 575-583.

Hu, H. and Gao, K. (2006). Response of growth and fatty acid compositions of Nannochloropsis sp. to environmental factors under elevated CO 2 concentration. Biotechnology letters 28(13): 987-992.

Jones, O. G. (2016). Recent advances in the functionality of non-animal-sourced proteins contributing to their use in meat analogs. Current Opinion in Food Science 7: 7-13.

Katoli, M. S. ; Nejadsattari, T. ; Majd, A. and Shokravi, S. (2015). Physiological, morphological and ultrastructural to combination responses of Cyanobacterium Fischerella sp. FS 18 effects of extreme conditions. J. Appl. Environ. Biol. Sci 5(1): 135-149.

Liu, B.-H. and Lee, Y.-K. (2000). Secondary carotenoids formation by the green alga Chlorococcum sp. Journal of applied phycology 12(3-5): 301-307.

Liu, J. and Hu, Q. (2013). Chlorella: industrial production of cell mass and chemicals.

López, C. V. G. ; García, M. d. C. C. ; Fernández, F. G. A. ; Bustos, C. S. ; Chisti, Y. and Sevilla, J. M. F. (2010). Protein measurements of microalgal and cyanobacterial biomass. Bioresource technology 101(19): 7587-7591.

Metsoviti, M. N. ; Papapolymerou, G. ; Karapanagiotidis, I. T. and Katsoulas, N. (2019). Comparison of growth rate and nutrient content of five microalgae species cultivated in greenhouses. Plants 8(8): 279.

Moorhead, K. ; Capelli, B. and Gerald, C. R. (2011). Spirulina Nature's Super food. published by Cyanotech Corporation, 73-4460 Queen Kaahumanu Hwy\# 102. KailuaKona, HI 96740.

Muller-Feuga, A. (2000). The role of microalgae in aquaculture: situation and trends. Journal of applied phycology 12(3-5): 527-534.

Muller-Feuga, A. (2013). Microalgae for aquaculture: the current global situation and future trends. Handbook of Microalgal Cultures: Applied Phycology and Biotechnology. 2nd ed. Wiley Blackwell, West Sussex: 615-627.

Pecegueiro do Amaral, M. F. (2012). Evaluation of algae concentration in manure based media PhD,182p.

Petkov, G. and Garcia, G. (2007). Which are fatty acids of the green alga Chlorella? Biochemical Systematics and Ecology 35(5): 281-285.

Platt, T. and Irwin, B. (1973). Caloric content of phytoplankton. Limnology and Oceanography 18(2): 306-310. 
Pulz, O. and Gross, W. (2004). Valuable products from biotechnology of microalgae. Applied microbiology and biotechnology 65(6): 635-648.

Rippka, R. ; Deruelles, J. ; Waterbury, J. B. ; Herdman, M. and Stanier, R. Y. (1979). Generic assignments, strain histories and properties of pure cultures of cyanobacteria. Microbiology 111(1): 1-61.

Roy, S. S. and Pal, R. (2015). Microalgae in aquaculture: a review with special references to nutritional value and fish dietetics. Proceedings of the Zoological Society, Springer.

Ru, I. T. K. ; Sung, Y. Y. ; Jusoh, M. ; Wahid, M. E. A. and Nagappan, T. (2020). Chlorella vulgaris: a perspective on its potential for combining high biomass with high value bioproducts. Applied Phycology 1(1): 2-11.

Safafar, H. ; Hass, M. ; Møller, P. ; Holdt, S. and Jacobsen, C. (2016). High-EPA biomass from Nannochloropsis salina cultivated in a flat-panel photo-bioreactor on a process water-enriched growth medium. Marine drugs 14(8): 144.

Safi, C. ; Zebib, B. ; Merah, O. ; Pontalier, P.-Y. and Vaca-Garcia, C. (2014). Morphology, composition, production, processing and applications of Chlorella vulgaris: A review. Renewable and Sustainable Energy Reviews 35: 265-278.

Schmidt, L. E. and Hansen, P. J. (2001). Allelopathy in the prymnesiophyte Chrysochromulina polylepis: effect of cell concentration, growth phase and $\mathbf{p H}$. Marine Ecology Progress Series 216: 67-81.

Sharma, K. K. ; Schuhmann, H. and Schenk, P. M. (2012). High lipid induction in microalgae for biodiesel production. Energies 5(5): 1532-1553.

StatSoft, I. (2011). Statistica (Data Analysis Software System), Version 10 (Tulsa, Oklahoma, USA, StatSoft Inc.).

Strickland, J. D. (1968). A practical handbook of seawater analysis. Bull. Fish. Res. Bd. Canada 167: 81-86.

Taheri, R. ; Shokravi, S. and Hossaianzadeh, M. (2017). Growth assessment of Cyanobacteria Anabaena SP. FS 76 and Nostoc SP. FS 77 affected by thermal shock conditions. Trakia Journal of Sciences 15(1): 5.

Tatsuzawa, H. ; Takizawa, E. ; Wada, M. and Yamamoto, Y. (1996). Fatty acid and lipid composition of the acidophilic green alga Chlamydomonas sp. 1. Journal of Phycology 32(4): 598-601.

Terry, N. and Abadía, J. (1986). Function of iron in chloroplasts. Journal of Plant Nutrition 9(3-7): 609-646.

Vareltzis, P. K. and Undeland, I. (2012). Protein isolation from blue mussels (Mytilus edulis) using an acid and alkaline solubilisation technique-process characteristics and functionality of the isolates. Journal of the Science of Food and Agriculture 92(15): 3055-3064.

Vasileva, I. ; Marinova, G. and Gigova, L. (2015). Effect of nitrogen source on the growth and biochemical composition of a new Bulgarian isolate of Scenedesmus sp. Journal of BioScience \& Biotechnology.

Wijffels, R. H. and Barbosa, M. J. (2010). An outlook on microalgal biofuels. Science 329(5993): 796-799.

Xia, L. ; Song, S. ; He, Q. ; Yang, H. and Hu, C. (2014). Selection of microalgae for biodiesel production in a scalable outdoor photobioreactor in north China. Bioresource technology 174: 274-280.

Zittelli, G. C. ; Rodolfi, L. ; Bassi, N. ; Biondi, N. and Tredici, M. R. (2013). Photobioreactors for microalgal biofuel production. Algae for biofuels and energy, Springer: 115-131. 